\title{
A Word from the Editor
}

The editorial board for Theological Librarianship (TL) met in January. At that meeting, we revised TL's scope: "Theological Librarianship is an open access journal publishing peer-reviewed articles, as well as essays and reviews, on subjects at the intersection of librarianship and religious and theological studies that potentially impact libraries." This revision came about for a couple of reasons. First, we desired clarity in our purpose and our vision, both to our readers and to future contributors. Second, while librarianship does have its distinctiveness as a discipline, there are also many facets of librarianship dependent upon integration with other knowledge fields. As Atla collects and connects in a specific knowledge field, the areas of religious and theological studies, the editorial team desired a scope that reflected this broad range of content that could come from connecting and collecting. With this modified scope, the editorial team hopes that you will reflect upon the many intersections taking place between religious and theological studies and librarianship and share what that connection looks like for you and consider sharing your thoughts by writing an article or an essay in $T L$.

A key dynamic of what brought about this revised purpose statement was $T L$ 's editorial team. With volume 13, issue 1 being my second issue, and being the first issue of two other editorial team members, I thought that this issue may be a good venue to introduce (or re-introduce for some) TL's editorial team. $T L$ has an excellent editorial team which strives to bring excellent content to our readers.

Richard "Bo" Adams, who is the Director of Pitts Theology Library and Margaret A. Pitts Assistant Professor in the Practice of Theological Bibliography. Bo has a unique combination of education in computer science, theology, and librarianship, making him a prime candidate for contributing to Atla and Theological Librarianship. Bo's research interests include reading communities, reading technologies, and reading practices. His role as editor of TL's critical reviews fits his interest in how reading impacts many facets of the $21^{\text {st }}$ century.

Chris Anderson, who works for the Yale Divinity Library in New Haven, Connecticut. His formal position title is Special Collections Librarian and Curator of the Day Missions Collection. Chris became a theological librarian in 2007, learned about Atla that year, and decided to join the organization and participate in the annual conference at Philadelphia. Chris has written a couple of articles and book reviews for $T L$ and he was asked to join the Advisory Board for the journal. He did that for a couple of years and then applied for one of the editorial positions and was appointed. Chris enjoys helping authors with their research and assisting them through the process of moving their ideas from theory to praxis.

Jesse Mann, who has served five years as the Theological Librarian at Drew University in Madison, New Jersey. In this position, his principle task is to support the research and teaching/learning needs of Drew Theological School's faculty and students. Jesse has been interested in Atla and its regional branch, NYATLA, since he began working at Drew in 2014. Atla has provided Jesse with essential information, resources, and camaraderie. Jesse joined the editorial board of $T L$ because he is interested in the scholarly communication and editing process (the production of "knowledge") and because he wants to be more actively connected with the issues and resources relevant to the LIS profession.

Kaeley McMahon, who is a Research and Instruction Librarian at the Z. Smith Reynolds Library at Wake Forest University. She is the liaison to the School of Divinity, the Department for the Study of Religions, and Jewish Studies, as well as to Art and Theatre \& Dance. Kaeley's first awareness of Atla 
was as an undergraduate student using the database in 1993, and Atla continued to be her database of choice while completing her MA, with the Proceedings as a major resource for several projects during her MLIS. The Portland conference in 2003 was her first Atla Annual conference, and she has been a regular attendee since 2010. Serving on the board of Theological Librarianship allows her an opportunity to give back to the organization and people who have shared so much wisdom and support over the years.

Garrett Trott, who is University Librarian at Corban University in Salem, OR. Corban University is a small Christian liberal arts school and, subsequently, as University Librarian he wears many hats. He joined TL's editorial team as editor-in-chief because he enjoys learning and saw this as an opportunity to learn more about publishing, resources, and Atla. It has been a fantastic learning experience thus far. Garrett got into librarianship for many of the same reasons-he enjoys learning and saw librarianship as an ever-changing profession with ample opportunities to learn, grow and serve.

Please enjoy the content of this issue of $T L$. The editorial team works hard to bring you content that is interesting and relevant to areas where theological and/or religious studies intersect with librarianship.

Soli Deo gloria

Garrett B. Trott 